\title{
РОЛЬ «БОЛЕЗНЕЙ» УПРАВЛЕНИЯ РОССИЙСКО-АМЕРИКАНСКОЙ КОМПАНИЕЙ В ФИНАНСОВОМ ПРОВАЛЕ ПРОЕКТА «РУССКАЯ АМЕРИКА»
}

\author{
(c) 2021 Лебедев Константин Николаевич \\ доктор экономических наук, профессор, профессор Департамента экономической теории \\ Финансовый университет при Правительстве Российской Федерации, Россия, Москва \\ E-mail: KNLebedev@fa.ru \\ ORCID: https://orcid.org/0000-0002-4846-8097
}

В настоящей статье сделана попытка приблизительно оценить стоимость заселения оставшейся незаселенной русскими к началу XIX в. части территории Русской Америки по таким статьям, как строительство поселений и создание флота, а также приблизительно подсчитать величину потерь Русско-Американской компании в начальный период ее деятельности (1799-1818 гг.) от дурного управления. Делается вывод, что вызванный этими потерями недостаток средств может служить объяснением остановки поселенческой экспансии русского пушного бизнеса в Северной Америке после его реорганизации в 1799 г. в монопольную акционерную компанию.

Ключевые слова: Российско-Американская компания, проект «Русская Америка», акционерное общество, плохой менеджмент, болезни управления.

В статье Ю.И.Будович и М.С.Будович «Провал проекта «Русская Америка» и погоня за прибылью Российско-Американской компании», опубликованной в настоящем номере журнала «Экономические науки», было показано, что передача в 1799 г. процесса хозяйственного освоения территории Русской Америки (РА) монопольной пушной Российско-Американской компании (РАК) привела к остановке поселенческой экспансии пушного русского бизнеса в РА (что и стало главной причиной провала проекта «Русская Америка» (Проекта)) потому, что у РАК, как у пушной компании с финансовой формой собственности, было крайне низким стремление к поселенческой экспансии, которое блокировал ряд присущих пушной компании симптомов такой главной болезни управления акционерными обществами (AO), как погоня за прибылью, и стремление решать проблемы краткосрочными мерами. Цель настоящей статьи - показать, что даже если бы у РАК в первоначальный период ее функционирования (1799-1818 гг.) и возникали позывы к поселенческой экспансии, их реализация упиралась бы в недостаток необходимых для нее средств, в образовании которого приняли участие все болезни управления, присущие предприятиям с финансовой формой собственности. Заметим, что поселенческая активность РАК за переделами Аляски в первые 20 лет деятельности компании сильнейшим образом за- висела от ее финансового состояния, о чем говорит то, что эта активность находила проявление именно в прибыльные годы - с 1812 по 1820 г. включительно (см. ниже). В 1812 г. в Калифорнии было построено постоянное поселение Росс, во время экспедиции Шеффера 1815-1817 гг. на Гавайских о-вах (вне территории РА) были построено 3 крепости, затем утраченные [12].

Так как речь идет о недостатке средств для реализации поселенческих планов пушной компании, потери РАК от дурного управления должны сравниваться с объемом средств, необходимых для заселения еще незаселенных земель РА. Конечно же, сразу возникает желание оценить стоимость строительства необходимого количества поселений. Это можно сделать на основе данных о стоимости строительства одного постоянного поселения и количестве необходимых поселений. Известно, что стоимость построек в Якутате, который был на момент уничтожения индейцами в 1805 г. вторым по стоимости строительства поселением на Аляске, составляла 31525 руб. [5] О таком же порядке стоимости строительства поселения говорят и данные об ущербе, нанесенном РАК экспедицией Шеффера, в ходе которой было построено 3 крепости (см. выше). Он был оценен в 200 тыс. руб., из которых часть ушла на покупку военного судна для одного из гавайских правителей [7]. Средняя стоимость постройки/приобретения корабля в 
1799-1818 гг. составляла у РАК 122 тыс. руб. (см. ниже). Отсюда, на одну крепость было потрачено в среднем 26 тыс. руб. ((200-122)/3). Для упрощения, будем считать стоимость постройки поселения равной 30 тыс. руб.

Для определения числа необходимых поселений вначале установим площадь РА без Аляски, т.е. суммарную площадь таких ее земель, как территории Юкон и Новая Каледония, страна Орегон и Калифорния, пределы которых были охарактеризованы нами в статье «Провал проекта «Русская Америка» и зависимость поселенческой активности русского колониального пушного бизнеса от формы собственности», напечатанной в данном номере журнала «Экономические науки». Территории Юкон и Новая Каледония и северная часть страны Орегон приблизительно соответствуют современным провинциям Юкон и Британская Колумбия, Канада, имеющим площадь 536,3 и 948,6 тыс. км² соответственно [2, с. 531], в связи с чем общая площадь этих земель составляла 1484,9 тыс. км ${ }^{2}$ $(536,3+948,6)$. Южная же часть страны Орегон соответствовала современным штатам Вашингтон, Орегон, Айдахо и частям штатов Монтана и Вайоминг, США, с общими площадями 179,0, 250,5, $217,3,380,7$ и 253,6 тыс. км² соответственно [2, с. 535]. Наложение очертаний южной части страны Орегон на административную карту США [21] показывает, что в нее входило приблизительно $20 \%$ территорий двух последних штатов. В таком случае площадь южной части страны Орегон составляла 773,6 тыс. км² $(179,0+250,5+217,3+380,7$ *20/100+253,6*20/100).

Калифорния представляла собой северную часть территории испанской колониальной провинции Верхняя Калифорния, лежащую выше 38-й параллели, ныне разделенную между современными штатами Калифорния, Невада, Юта, Вайоминг и Колорадо, США. Общие площади этих штатов равны 410,0, 286,7, 220,1, 253,6, 269,2 тыс. км² соответственно [2, с. 535]. Наложение на административную карту США [21] очертаний Верхней Калифорнии [3] показывает, что в ее северную часть (выше 38-й пар.) входят приблизительно 40, 75, 80, 20 и 50\% территорий перечисленных выше штатов соответственно, т.е. площадь Калифорнии составляла 740,4 тыс. км ${ }^{2}((410,0 * 40+286,7 * 75+220,1 * 80+253,6 * 20$ $+269,2 * 50) / 100)$.

Сложив площади соответствующих земель, получим, что к 1800 г. незанятая русски- ми территория РА равнялась 2998,9 тыс. км² $(1484,9+773,6+740,4)$, или около 3 млн. км². Какое же количество постоянных поселений нужно было на ней устроить, чтобы эта территория была признанной занятой Россией? Очевидно, нужно исходить из плотности постоянных поселений, достижение которой было бы признано заселением страны, прежде всего, США, превращавшимися в главного территориального конкурента России в Северной Америке (СА). США в конце 1814 г. сразу после завершения англо-американской войны, начавшейся в 1812 г., заявили Великобритании о своих правах на страну Астория [14], основав в ней всего 3 постоянных поселения - построенные в 1811 г. американской Тихоокеанской пушной компанией (ТПК) в бассейне р. Колумбия Форт-Асторию и 2 поселения-спутника Вилламетт и Оканагон, которые ТПК была вынуждена продать британской Северо-Западной пушной компании (СЗК) в 1813 г. во время войны, исходя из того, что они все равно будут захвачены англичанами, так как у американцев в регионе не было военной силы для их защиты [22]. Наложение на карту штата Вашингтон, США [18], очертаний Астории [14] показывает, что последняя занимала около 60\% территории штата, т.е. площадь Астории составляла 107,4 тыс. км² (179,0*60/100). Плотность поселений, достижение которой США считали своим заселением страны Астория, таким образом, составляла 1 поселение на 35,8 тыс. км² $(107,4 / 3)$. Отсюда, для занятия 3 млн. км$^{2}$ по меркам США потребовалось бы построить 84 постоянных поселения $(2998,9 / 35,8)$.

Исходя из стоимости строительства одного поселения, равной 30 тыс. руб., и нужного для признания соответствующих земель заселенными русскими количества образованных на них поселений, равного 84, общие затраты на строительство поселений для занятия оставшейся части РА составляли 2,52 млн. руб. (84*30/1000).

Но главной статьей расходов пушной компании, осуществляющей поселенческую экспансию, очевидно, являются затраты на создание флота, который нужен не столько для разведки мест для строительства поселений и завоза в них строителей и необходимых материалов (что совмещалось и осуществлялось пушной компанией за одну экспедицию, как это было сделано ТПК - см. выше), сколько для транспортного обслуживания данных поселений после их создания. В 1819 г. у РАК был флот из 13 кораблей, 
обслуживавших 15 постоянных поселений, которыми на тот момент располагала Россия в СА (14 - на Аляске, 1 - в Калифорнии) [11]. Будем считать, что 13 кораблей было достаточно для нормального обслуживания 15 поселений. Об этом говорит то, что к 1819 г. полностью прекратились совместные с иностранцами экспедиции «из половины» (когда добытая пушнина делилась поровну), которые американцы и пр. обеспечивали судами и экипажами, а русские байдарками и охотниками, свидетельствующие о недостатке судов у РАК. Последняя такая экспедиция была организована с французами в 1818 г. с участием торгового судна «Ле Бордэле» капитана Камиля де Рокфейна, тогда как совместные экспедиции с американцами прекратились еще с началом англо-американской войны в 1812 г. [20].

Исходя из нормы обеспеченности поселений кораблями, равной 0,87 корабля на поселение (13/15), для нормального обслуживания дополнительных 84 поселений РАК должна была увеличить свой флот на 73 корабля $\left(0,87^{*} 84\right)$. За первые 20 лет РАК истратила на создание флота 3,3 млн. руб., причем из 32 приобретенных ею судов 5 было получено в качестве взносов в уставный капитал [11]. Таким образом, за эти годы флот РАК увеличился на 8 кораблей (13-5). При этом 19 судов выбыло, из них 16 - из-за несчастных случаев. Большинство же последних произошло, как признавало само правление РАК, из-за нерадивости и неискусста штурманов из Охотска [11], т.е. не менее $9(16 / 2+1)$. Средняя стоимость постройки/покупки корабля составляла 122 тыс. руб. (3300/(32-5)). Отсюда, ущерб, нанесенный компании нерадивостью охотских штурманов, составил за рассматриваемый период 1,1 млн. руб. (122*9/1000). Наем же нерадивых штурманов из Охотска был управленческой ошибкой А.А.Баранова, который не хотел нанимать более дорогих, но значительно более квалифицированных, капитанов, уволенных из военного флота. Понятно, что эта ошибка является ярким симптомом погони РАК за прибылью. Таким образом, для увеличения флота до 13 судов РАК должна была без этой ошибки израсходовать всего 2,2 млн. руб. (3,3-1,1). Тогда для увеличения остатка кораблей на 1 ед. она должна была потратить 0,275 млн. руб. (2,2/8). Отсюда, для увеличения флота еще на 73 корабля нужно было за 20 лет потратить 20,1 млн. руб. (0,275*73). Таким образом, всего на увеличение числа посто- янных поселений до необходимого для полного заселения русскими территории РА требовалось 22,62 млн. руб. $(20,1+2,52)$. С этой суммой как раз и соизмеримы потери РАК от дурного управления, характеризуемого в настоящей статье в терминах болезней управления и их симптомов, за период 1799-1818 гг.

Покажем, как дурное управление РАК, соответствующее разным болезням управления АО, сокращало средства компании, которые могли быть направлены на создание и обеспечение транспортного обслуживания сети постоянных поселений в оставшейся незаселенной части PA. Заметим, что само главное правление РАК незадолго до ее 50-летия характеризовало период деятельности РАК до 1821 г. как «период неустройства и несоответственного употребления способов и богатств компании» [13], т.е. фактически характеризовало его как период плохого менеджмента.

Нами в наших работах на основе изучения соответствующих симптомов были выделены следующие «хронические» болезни управления предприятиями с финансовыми капитальными системами (финансовой формой собственности), порождаемые финансовым (бесплатным или неэквивалентным) способом наделения предприятий (в лице их топ-менеджмента) собственными средствами: 1) предпочтение краткосрочной прибыли долгосрочной («погоня за прибылью»), 2) предпочтение социального развития предприятия его производственному развитию, 3) небрежное отношение топ-менеджмента к своим обязанностям, 4) воровство имущества предприятия [9, с. 493-494]. Дурное управление предприятиями с финансовыми капитальными системами, состоящее в этих болезнях (их симптомах), и обусловливает меньшую эффективность их деятельности по сравнению с таковой предприятий с нефинансовыми системами наделения собственным капиталом. Данные болезни управления обусловили и меньшую эффективность функционирования российской американской колониальной экономики после ее реорганизации в АО, сокращая ее финансовые возможности для поселенческой экспансии.

Главной болезнью управления АО является погоня за прибылью, а ее главным симптомом, по мнению основоположников марксизма, выступает расширение производства в том виде деятельности, который в данный момент приносит максимальную прибыль, да еще и в пределах 
всего доступного капитала, т.е. без учета общественных потребностей, что чревато кризисами перепроизводства со всеми их негативными последствиями (банкротство фабрикантов, ухудшение положения трудящихся, революция и т.д.) [9, с. 488-489]. Можно сказать, что РАК с самого начала своей деятельности была в полной мере поражена такой болезнью управления, как погоня за прибылью, так как РАК изначально был присущ ее главный симптом. Заготовка пушнины в те времена приносила максимальную прибыль. Так, цена одной шкурки морской выдры (он же - морской бобр, или калан.- примеч. авт.) достигала 2-годичной зарплаты рабочего пушных складов в Северном Китае [23], шкурки каланов приносили в 1-й четверти XIX в. прибыль 700-1100\% в год [8]. РАК и вкладывала все имеющиеся средства в добычу пушнины. В связи с этим последствия главного симптома погони за прибылью в деятельности РАК и не замедлили появиться. Ими стало перепроизводство РАК шкур морского котика уже в первые годы ее деятельности. Оно обернулось резким падением цены, в том числе и в немалой степени по причине снижения качества шкур из-за введения неадекватного способа их сушки. Из-за огромного количества добываемых шкур их не удавалось высушить на солнце в течение короткого лета, в связи с чем было решено сушить их в жарко натопленных банях, от чего шкуры зачастую либо сопревали, когда волос сходил с кожи, или даже сгорали, когда при сгибании ломались как кора дерева. К 1802 г. таким способом было испорчено 800 тыс. шкур. Правление РАК в 1803 г. писало «правителю Русской Америки», т.е. управляющему РАК, А.А.Баранову, что на островах скопилось около миллиона шкур, а в Кяхте - месте торговли шкурами с Китаем в Сибири, из прежде вывезенных шкур продается крайне мало, причем по цене 2 руб. за штуку, тогда как 4 года назад (в год основания РАК - примеч. авт.) цена была 6-7 руб. Тогда для повышения цены, в том числе, за счет повышения качества шкур, было решено сжечь несколько сот тысяч шкур морского котика. Сжигание шкур как способ поднятия цены практиковалось и после того, как их перестали сушить в банях. Оно имело место в 1810, 1811, 1812 и 1813 гг., причем в 1811 и 1812 г., когда в Иркутске и Охотске под надзором полиции было сожжено несколько сот тысяч шкур морского котика, многие купцы желали приобрести эти шкуры, но им было отказано [11]. В Уналашке (на Алеутских о-вах) в 1802 г. скопилось 800 тыс. шкур, продолжавших преть годами в земляных амбарах, из которых было уничтожено не менее 700 тыс. Ущерб от уничтожения шкурок только в Иркутске и Охотске составил 800 тыс. руб. [16] Не сложно подсчитать, что только уничтоженные в Уналашке 700 тыс. шкур могли быть проданы в Кяхте китайцам за 4,9 млн. руб. (7*700/1000), в случае, если бы РАК не допустила перепроизводства шкур морского котика и снижения их качества. Общие потери от уничтожения шкур в Уналашке, Иркутске и Охотске составили 5,7 млн. руб. $(4,9+0,8)$.

Как писал известный исследователь деятельности РАК С.Б. Окунь, падение цен на котика и затратные методы их повышения уже в первые годы деятельности РАК обусловили ее предбанкротное состояние, капитал, с которого РАК начала свою деятельность, оказался израсходованным. В связи с этим компании пришлось прибегать к займам - первые 250 тыс. руб. были взяты для отправки в 1803 г. первой кругосветной экспедиции для снабжения колонии товарами отечественного производства, а к 1807 г. долг РАК достиг 2394,4 тыс. руб., что на 1 млн. руб. было больше акционерного капитала РАК (723 тыс. в виде имущества, имевшегося в колониях на момент учреждения РАК, и 515,8 тыс. руб., внесенных наличными новыми акционерами после), этот долг не был обеспечен ничем, кроме надежд на случайную перемену обстоятельств, так что малейшее потрясение кредита могло привести к падению РАК. В эти годы РАК искусственно выводила прибыль, добавляя ее к складочному капиталу, так что по данным РАК капитал компании в 1807 г. был равен 3028,3 тыс. руб., но баланс за 1808-1809 уже официально был убыточным [11]. Очевидно, он был официально убыточным и за 1810-1811 гг., так как цена акции РАК за эти годы была выведена ниже номинала 500 руб. -472 руб. 38 коп. и 475 руб. 4 коп. соответственно [11].

Понятно, что в эти годы (до 1812), даже при возникновении у РАК вынужденных позывов к поселенческой экспансии, например вследствие интенсификации нападений индейцев или сокращения поголовья животных в местах традиционного промысла из-за их хищнического истребления, что требует закрепления за пушной компанией новых промысловых угодий, у РАК просто могло не быть для нее средств. В таком случае отсутствие средств было и главной при- 
чиной попыток решения проблемы закрепления за РАК новых мест промысла на морского зверя краткосрочными, т.е. весьма ненадежными, методами, например путем подписания А.А.Барановым договора с американским купцом Дж. Дж Астором о разделе зоны добычи вдоль северозападного побережья СА - к русским отходила ее часть выше $55^{\circ}$ с.ш., а к американцам - ниже [20], путем организации совместных с американскими купцами промысловых экспедиций «из половины» в южные районы (см. выше).

Причиной предбанкротного состояния РАК в период до 1812 г. был не только рассмотренный выше симптом погони за прибылью, но и такой симптом этой болезни, приведенный в вышеуказанной статье Ю.И.Будович и М.С.Будович, как недостаточная забота о собственном производстве всего необходимого для снабжения пушной колониальной компании, находящий проявление в закупке нужных ей товаров на стороне. Товары закупались или в России, доставляясь на кораблях, шедших из Охотска и Кронштадта, или у иностранных купцов, заходивших в русские колониальные порты. При этом товары, поступавшие из России, были менее качественными и более дорогостоящими, чем поставлявшиеся иностранными купцами [19]. Очевидно, что наиболее дорогостоящим было снабжение РАК путем доставки товаров из Кронштадта, т.е. посредством кругосветных экспедиций. Как раз в первые годы деятельности РАК, а именно в 1803 г. и в 1806 г., для ее снабжения были снаряжены 1-я и 2-я кругосветные экспедиции (следующие - с 1813 г.). Такое снабжение было не только очень дорогостоящим, но и малоэффективным, о чем говорят соответствующие данные о кругосветных экспедициях 1819-1821 гг. Они обошлись РАК в 2400 тыс. руб., и при этом экспедиция 1820 г. на корабле «Кутузов», стоившая PAK 700 тыс. руб., привезла товаров только на 200 тыс. руб. [11] Таким образом, убыток только от одной кругосветной экспедиции мог составить 0,5 млн. руб. ((700-200)/1000). О том, что данный симптом погони за прибылью пушной колониальной компании существенно влиял на финансовое состояние РАК, говорят колебания в ее прибыльности, очевидным образом связанные с изменениями в соответствующем способе снабжения РАК. Так, РАК становится прибыльной с 1812 г. после принятия решения о ее снабжении товарами преимущественно иностранного производства, приобретаемыми у иностранных купцов, заходящих в русские колониальные порты. О прибыльности можно судить по выплате дивидендов. И на самом деле, за 1814-1815 гг. на 500-рублевую акцию было выплачено по 100 руб. 28 коп., за 1816-1817 гг.- 150 руб., за 18181819 гг.- 155 руб., или по 31\% за двухлетие [11]. При этом, очевидно, дивиденды платились уже и за 1812-1813 гг., так как рыночная стоимость акции была выше номинала 500 руб., а именно составляла 550 руб. [11] После же того, как в августе 1820 г. соответствующая торговля с иностранцами была запрещена [11], деятельность РАК вновь становится убыточной. И на самом деле, за 1820-1821 гг. дивиденды сокращаются до 82 руб. на акцию, а за 1822-1823 гг. вообще не выплачиваются, поскольку РАК получает убыток в 300 тыс. руб. [11] Понятно, что в случае развития собственного производства товаров, необходимых для обеспечения ее деятельности, РАК до 1812 г. была бы менее убыточной, а после - более прибыльной.

Не сложно оценить ущерб, который наносил компании только переход к снабжению путем завоза товаров из Охотска и Кронштадта. За первые 20 лет деятельности чистая прибыль РАК составила 6,25 млн. руб. [11] Очевидно, что она была получена за прибыльные годы, которых было 9 (1812-1820 гг.), если исходить из того, что 1821 г. был уже убыточным. Среднегодовая чистая прибыль, таким образом, составила в эти годы 694 тыс. руб. (6250/9). Отказ от снабжения путем покупки товаров у иностранцев привел к появлению у РАК убытка в размере 300 тыс. руб. за двухлетие (см. выше), или 150 тыс. руб. в год (300/2). Отсюда, с таким переходом компания лишалась 844 тыс. руб. в год (694+150). Следовательно, потери РАК от снабжения путем завоза товаров из Охотска и Кронштадта до перехода на снабжение преимущественно путем торговли с иностранцами, т.е. за 1800-1811 гг., или за 12 лет (1811-1800+1), могли составить 10,1 млн. руб. (844*12/1000). При этом переход от одного способа внешнего снабжения к другому имел явную коррупционную составляющую - члены главного правления наживались на кругосветных экспедициях (см. ниже).

Таким образом, можно сказать, что в течение первых 20 лет своей деятельности такая болезнь управления РАК, как погоня за прибылью, не только делала крайне слабым ее стремление к поселенческой экспансии, но и лишала компанию необходимых для нее средств. 
Активную роль в лишении РАК финансовых средств, которые могли бы быть направлены на строительство и обеспечение обслуживания новых постоянных поселений, сыграла и такая болезнь управления предприятиями с финансовой формой собственности, как предпочтение социального развития предприятия его производственному развитию, симптомами которой являются, в частности, приоритетность наполнения фондов заработной платы, материального поощрения и социального развития по сравнению с фондами производственного и научно-технологического развития (что имело место на советских госпредприятиях, получивших в конце 1980-х полную хозяйственную самостоятельность) [10, с. 253], завышение вознаграждений топ-менеджеров [9, с. 494].

Специфическим для АО симптомом предпочтения социального развития производственному развитию являются завышенные (по сравнению уровнем, необходимым для достижения объективных целей производственного развития) дивиденды. Не сложно установить, что уровень дивидендов, выплачивавшихся за 1814-1819 гг., был очень высоким, непозволительным для развивающейся компании, особенно за 1818-1819 гг. Рыночная стоимость акции РАК за 1818-1819 гг. составила 574 руб. 28 коп. [11], а дивиденды за это двухлетие были начислены в сумме 155 руб. (см. выше). Отсюда, дивидендная доходность акций РАК составила в рассматриваемые 2 года целых 13,5\% годовых $((155 / 2) / 574,28 * 100))$, что было гораздо выше доходности других финансовых инструментов в стране. Так, С.Б. Окунь отмечал, что дивиденды выплачивались компанией в размерах, значительно превышавших учетный процент [13]. Для сравнения, автор финансовой пирамиды Джон Ло только обещал (даже не выплатил) выплатить 12\% годовых от номинала (500 ливров) на акции своей Миссисипской компании в целях стимулирования спроса на них, когда их рыночная цена составила 1000 ливров за акцию [4, с. 17-18], т.е. дивидендная доходность акций Миссисипской компании должна была составить только 6\% ((500*12/100)/1000*100), что более чем в 2 раза ниже таковой РАK $(13,6 / 6=2,3)$. Однако наши расчеты показывают, что дивидендная доходность акций РАК была значительно выше, чем подсчитанная исходя из данных о дивидендах на акцию и о ее рыночной стоимости. Даже их средняя за 9 прибыльных лет (1812-1820 гг.) дивидендная доходность была выше рекордной доходности акций, якобы достигнутой за 1818-1819 гг. Согласно отчетам компании, за (первые) 20 лет деятельности на 1,24 млн. руб. ее капитала было получено 6,25 млн. руб. чистой прибыли, из которой 3,06 млн. было выплачено акционерам [11]. Если исходить из того, что в 1812-1820 гг. рыночная стоимость акции с номиналом 500 руб. составляла 550-575 руб. (см. выше), или в среднем 562,5 руб. $((550+575) / 2)$, т.е. $112,5 \%$ от номинала $(562,5 / 500 * 100)$, то рыночная стоимость капитала РАК в этот период составляла в среднем 1,395 млн. руб. $(1,24 * 1,125)$. Средняя дивидендная выплата составляла за эти годы 0,34 млн. руб. (3,06/9). Отсюда, среднегодовая дивидендная доходность акций компании составляла в 1812-1820 гг. 24,4\% годовых (0,34/1,395*100).

Если считать нормальной дивидендную доходность акций, равную 6\% (см. выше), то РАК за 20 лет переплатила своим акционерам дивидендов на сумму 2,3 млн. руб. (3,06/24,4*(24,4-6)).

В компании имело место завышение вознаграждений топ-менеджеров. После впадения РАК в очередное предбанкротное состояние (1822-1826 гг., когда дивиденды не выплачивались) в ходе проверок выяснилось, что каждый из директоров компании имел жалованье 15 тыс. руб. в год, по крайней мере, один из директоров (Прокофьев) получал столовые деньги в размере 12 тыс. в год и один из директоров (Булдаков) дополнительно к жалованью получал еще и пенсию в размере 10 тыс. руб. в год, а в период катастрофического финансового положения каждый из директоров получил еще и наградные деньги в размере 100 тыс. руб. [11] В то время жалованье гражданских губернаторов по I и II разрядам (установленное штатным расписанием от 1802 г.) составляло 1800 и 2250 руб. (ассигнациями), а их столовые деньги - 1200 и 3600 руб. соответственно, и только по штатному расписанию от 1835 г. эти суммы выросли до 6000 и 7500 руб. соответственно (жалованье было равно столовым деньгам) [1, с. 24]. Таким образом, директор РАК получал только жалованье почти в 7 раз более высокое, чем таковое у начальника российской губернии II разряда $(15000 / 2250=6,67)$. Неслучайно за период 1808-1820 гг. РАК израсходовала на снабжение и содержание колоний 2,32 млн. руб., тогда как на содержание главного правления компании в Петербурге, в котором было всего 4 директора [7], было израсходовано 4,7 млн. руб. [11], т.е. на 
содержание топ-менеджмента РАК ушло в 2 раза больше денег $(4,7 / 2,32=2,03)$, чем на содержание всего остального персонала РАК и закупку пушнины у индейцев.

Если расходы на содержания правления все первые 20 лет имели тот же уровень, что и в 1808-1820 гг. (см. выше), то за два десятилетия на содержание правления ушло 7,2 млн. руб. $(4,7 / 13 * 20)$. Даже если считать затраты на содержание правления завышенными только в 2 раза, то РАК за 20 лет по данной причине лишилась 3,6 млн. руб. (7,2/2).

Следует отметить, что в случае наличия у РАК достаточных финансовых ресурсов совершенно по-иному могла сложиться судьба страны Орегон, даже исходя из реалий 1813 г. В 1811 г. Россия по большому счету потеряла шансы на мирный захват страны Орегон или хотя бы ее части в связи с тем, что в 1811 г. американская ТПК основала в бассейне р. Колумбия сеть постоянных поселений, образовавших страну Астория, которые затем были вынужденно проданы британской СЗК (см. выше). По нашему мнению, более логичной для ТПК была продажа Астории РАК, так как цена продажи была бы выше, а враждебная страна не укрепилась бы в регионе, причем Великобритания никак на факт такой продажи не среагировала бы, так как предъявлять свои права на какие-либо земли в стране Орегон в то время не собиралась [14]. Такая сделка между ТПК и РАК вполне могла планироваться, учитывая близкое знакомство Дж. Дж. Астора и А.А. Баранова (см. выше). И, как нам представляется, она не состоялась именно из-за того, что РАК, начав получать прибыль только с 1812 г. (см. выше), предпочла приберечь ее для выплаты долгожданных акционерами дивидендов, а не пустить ее на производственное развитие компании.

Предпочтение социального развития производственному развитию, как было показано выше, означает наполнение во 2-ю очередь фонда не только производственного, но и научнотехнологического развития предприятия. При этом в случае РАК можно сказать, что фонд ее научно-технологического развития в положительном смысле вообще не наполнялся, так как РАК все время своего существования использовала для выделки шкур один и тот же, да еще и самый примитивный метод, что обусловливало низкое качество российских шкур по сравнению с иностранными и, естественно, более низкую цену продукции и занижение доходности РАК по соответствующей причине. Добытые шкуры подвергались только одной операции - сушке на воздухе на солнце, будучи растянутыми на «пялах», как это делали еще промышленникипионеры Алеутских о-вов. В связи с этим ценнейшее сырье, которым располагала РАК, превращалось в меха среднего и низкого качества, которые за границей шли только на восточные рынки, прежде всего в Китай, тогда как европейские потребители меха, выделанные РАК, не покупали. И когда, уже под конец своего существования, компания попыталась вывозить пушнину в Лондон, у нее брали не выработанный мех, а шкуры, засоленные в бочках [11]. Естественно, такие шкуры сбывались (частично и в НьюЙорке) задешево [13]. Справедливости ради, отметим, что фонд научно-технологического развития РАК все же один раз наполнялся - в начале ее деятельности, когда на его средства был разработан и внедрен новый способ сушки меха (в жарко натопленных банях), приводивший к тому, что шкуры сопревали или сгорали (см. выше). РАК пыталась в конце своей деятельности наладить выделку шкур по последнему слову техники. Так, в 1865 г. в Лондон для изучения постановки дела на фирме Оппенгеймер и Ко был направлен служащий РАК Рутковский, который убедился в том, что котовые шкуры, которые берут на лондонском рынке, имеют шерсть и пух гораздо рослее и гуще, чем шкуры русского производства. РАК также пыталась переманить к себе мастеров из лондонского торгового дома Лемпсона. Однако все эти начинания ни к чему не привели [13].

Мы даже не пытались оценить, очевидно, гигантский ущерб от производства низкокачественной продукции при самом высоком в мире качестве пушного сырья, которым располагала РАК, так как убытки, уже отмеченные выше, в общей сумме составив 22,8 млн. руб. $(1,1+5,7+10,1+2,3+3,6)$, уже перекрыли сумму, которая была нужна РАК для создания в незанятой части РА необходимого для ее занятия количества постоянных поселений и флота для транспортного обеспечения их функционирования, определенную нами в 22,62 млн. руб. Остальной ущерб может быть мысленно направлен на финансирование статей соответствующих расходов, которые нами не были учтены в этой сумме, или на создание поселений на островах в Тихом океане. 
Очевидно, что лепту в обеднение финансов РАК в период, когда она могла мирно занять всю намечавшуюся Проектом территорию в СА, и такая болезнь управления АO, как небрежное отношение топ-менеджмента к своим служебным обязанностям. Даже в рамках выбранной недальновидной стратегии (максимизация прибыли, предпочтение социального развития) РАК могла сэкономить значительные средства, которые могли пойти на реализацию Проекта, не совершай ее топ-менеджмент управленческих ошибок. Как, если не управленческой ошибкой, можно назвать строительство Михайловской крепости на о. Ситха в 1799 г. в месте, дающем воинственным тлинкитам наилучшие возможности для ее захвата. Она была захвачена ими в 1802 г. и восстановлена русскими только в 1804 г., будучи построенной уже на новом месте, а именно на горе, на которой раньше находилось селение самих тлинкитов [11]. Таким образом, стратегический пункт для реализации грандиозного плана по колонизации РА (Новоархангельск) не действовал в течение двух самых богатых возможностями для реализации Проекта лет, а средства, которые в ином случае могли пойти на строительство новых поселений и развитие флота, были потрачены на восстановление крепости из-за соответствующей ошибки А.А.Баранова. Прямой финансовый ущерб от уничтожения индейцами Михайловской крепости, поселения Якутат в 1805 г. и одного селения в юго-восточной Аляске составил не менее полмиллиона руб., причем Новоархангельск был самым дорогим поселением на Аляске [16], так что большая часть ущерба, очевидно, пришлась на него, в связи с чем ущерб от создания Михайловской крепости в неудачном месте можно оценить как минимум в 250 тыс. руб. (500/2). Как, если не управленческой ошибкой, можно назвать учреждение колонии Росс в 1812 г. помощником А.А.Баранова А. Кусковым на побережье Калифорнии в месте, плохо пригодном для ведения сельского хозяйства, тогда как эта колония предназначалась для обеспечения всех русских поселений продовольствием путем его собственного производства. В частности, урожайность злаковых на принадлежавших русским участках была в 10-20 раз ниже урожайности более отдаленных от океана земельных участков, из-за сильной влажности, обусловленной близостью к морю, вызывающей у злаков «ржавчину». В результате производимого продовольствия хватало главным образом для собственного обеспечения колонии Росс. Как установил прибывший в Форт-Росс в 1824 г. декабрист Д.И.Завалишин, эта колониальная русская «житница», призванная снабжать хлебом, как выясняется, не только РА, но и Камчатку, засевала только 200 пудов пшеницы и 40 пудов ячменя. В 1830-е гг. колония Росс приносила РАК убыток 10 тыс. руб. в год [12]. Вряд ли он был меньше в рассматриваемый период деятельности РАК, и в таком случае за 1812-1818 гг. функционирования колонии Росс РАК могла потерять 70 тыс. руб. (10*(1818-1812+1)).

Очевидно, в лишении РАК средств, которые в ином случае могли бы пойти на развитие сети постоянных поселений русских в РА в первые 20 лет ее существования сыграла и коррупция, в виду хронического характера данной болезни у АО. Конечно же, наиболее громкие коррупционные скандалы, указывающие на факты коррупции, могли возникнуть лишь тогда, когда Компания переставала выплачивать дивиденды. Это впервые имело место уже за пределами рассматриваемого 20-летнего периода, когда после запрета торговли с иностранцами в 1820 г. (см. выше) РАК вошла в зону убытка, в связи с чем дивиденды за 1822-1823 гг. не выплачивались. Тогда акционерами РАК были выявлены многочисленные факты коррупции среди топ-менеджмента РАК, разумеется, наиболее свежие по времени, что позволяет выяснить масштабы отдельных случаев воровства в компании. Когда в 1821 г. было решено организовать очередную кругосветную экспедицию, одним из директоров РАК был В.Крамер, и его торговому дому (братьев Крамер) правление получило купить корабль для этой экспедиции. В. Крамер купил его (судно «Елена») в США и как директор торгового дома положил себе в карман 6\% комиссионных. И когда Елена была уже недалеко от Кронштадта, В. Крамер купил для компании еще одно, полусгнившее судно «Елизавета» за 30 тыс. руб., причем у своего несостоятельного должника, т.е. за счет РАК вернул себе долг, а РАК была вынуждена потратить на ремонт судна 70 тыс. руб. «Елене», так как экспедицию уже отправили, осталось простаивать на рейде в Кронштадте, а «Елизавета», отправленная вместе с «Рюриком», еле дошла до м. Доброй Надежды, где ее вместе с грузом пришлось продать с убытком, а часть ее команды - отправить пассажирами в Петербург [11]. Общий ущерб от этой махинации составил 200 тыс. руб. [7] Несмотря на то, что этот случай 
не относится к 1799-1818 гг., все же он позволяет оценить масштабы коррупции в РАК в первые 20 лет ее деятельности и ее влияние на финансовое состояние компании и, соответственно, на ее поселенческую активность в этом периоде. Дело в том, что период деятельности РАК с 1821 по 1838 г., на который приходится данный коррупционный случай, характеризовался главным правлением РАК незадолго до ее 50-летия как период постепенного введения отчетности и порядка [11]. Если один коррупционный случай в этом периоде мог приводить к утрате компанией почти 2 кораблей (средняя стоимость корабля составляла 122 тыс. руб.- см. выше), то каковы были масштабы воровства в период (до 1821 г.), характеризовавшийся главным правлением как время неустройства и несоответственного употребления способов и богатств компании (см. выше)? В этом периоде (до 1821 г.) воровство в РАК процветало и на самом низшем уровне. Так, в Уналашке, где в 1802 г. скопилось 800 тыс. шкур морского котика, из 700 тыс. шкур, числившихся уничтоженными (см. выше), многие шкуры были нормальными. Их присвоили себе промышлен- ники (промысловые рабочие), которые после вывоза шкур в Охотск продали их купцам [16]. Известно, что котиковая шкура стоила в Охотске 2 руб. [15] Отсюда, даже если промышленниками было украдено хотя бы 10\% шкур, РАК получила ущерб (недополученный доход) в размере 140 тыс. руб. (2*700*10/100). В Кяхте же РАК могла получить за них, не допусти она перепроизводства и снижения качества шкур морского котика, 490 тыс. руб. (7*700*10/100). Правда, этот ущерб вошел в состав уже подсчитанного выше ущерба от уничтожения шкур в Уналашке.

Таким образом, доказано, что в первые 20 лет деятельности Российско-Американской компании даже при возникновении у нее вынужденных позывов к территориальной экспансии в Русской Америке в виде расширения сети своих постоянных поселений, таковая по большей части не могла осуществляться из-за недостатка необходимых для такой экспансии средств, обусловленного всеми хроническими болезнями управления АО, в форме которого была учреждена PAK.

\section{Библиографический список}

1. Бикташева А.Н., Гасимова А.А. Источники материального обеспечения российских губернаторов первой половины ХІХ века // Ученые записки Казанского государственного университета. 2009. Том 151. кн. 2., ч. 2. C. 19-27.

2. Бови А. Северная Америка / Пер. с франц.- М.: Государственное издательство географической литературы, 1948. 548 (XII) c.

3. Верхняя Калифорния / Tlaxcala territory-Alchetron, The Free Social Encyclopedia. URL: https://alchetron.com/ cdn/tlaxcala-territory-e0474c73-5fbd-4bd9-8a61-cc09265b853-resize-750.jpg (дата обращения: 10.09.2021).

4. Вирт М. История торговых кризисов в Европе и Америке Макса Вирта / пер. с нем. Е.И. Конради.- СПб.: Издание редакции журнала «Знание», 1877. 494 (XV) с.

5. Гринев А.В. Индейцы эяки и судьба русского поселения в якутате / www.booksite.ru. URL: https://www. booksite.ru/fulltext/russ_america/04_32.html (дата обращения: 21.07.2021).

6. Денежкина М., Марчант Т. История Калифорнии от древних времен до американской аннексии / Миртесен. 14.03.2014. URL: https://s30556663155.mirtesen.ru/blog/43972272253/Istoriya-Kalifornii-ot-drevnih-vremendo-amerikanskoy-anneksii (дата обращения: 08.08.2021).

7. Ермолаев А.Н. Главное правление Российско-Американской компании: состав, функции, взаимоотношения с правительством, 1799-1871/www.booksite.ru. URL: https://www.booksite.ru/fulltext/russ_america/05_24. html (дата обращения: 10.09.2021).

8. Князев С. Как Россия потеряла Аляску, Калифорнию, Гавайи и .../ Миртесен. 16.12.2015. URL: https://russianpresident.mirtesen.ru/blog/43297850090/Kak-Rossiya-poteryala-Alyasku,-Kaliforniyu,-Gavayi-i-... (дата обращения: 26.06.2021).

9. Лебедев К. Н. Финансовые и нефинансовые «капитальные» системы ресурсообеспечения и качество управления предприятиями // Экономические науки. 2020. № 12 (193). C. 488-497. DOI: 10.14451/1.193.488.

10. Лебедев К.Н. «Финансовый» характер собственности на средства производства в СССР и кризис советской экономики // Экономические науки. 2020. № 11 (192). С. 250-259. DOI: 10.14451/1.192.250.

11. Окунь С.Б. Российско-американская компания. III. Начало деятельности Российско-Американской компании / www.booksite.ru. URL: https://www.booksite.ru/fulltext/russ_america/05_15_3.html (дата обращения: 26.08.2021). 
12. Окунь С. Б. Российско-американская компания. VI. Поселение «Росс» в Калифорнии / www.booksite.ru. URL: https://www.booksite.ru/fulltext/russ_america/05_15_4.html (дата обращения: 26.08.2021).

13. Окунь С.Б. Российско-американская компания. VIII. Положение промысловых рабочих в русских поселениях в Америке / www.booksite.ru. URL: https://www.booksite.ru/fulltext/russ_america/05_15_5.html (дата обращения: 26.08.2021).

14. Орегонский вопрос: Англо-американский территориальный спор на северо-западе Америки / Северная Америка. Век девятнадцатый. URL: https://america-xix.ru/great-migration/oregon/question.html (дата обращения: 09.08.2021).

15. Первопроходчество. Глава 1. Русские колонии на Аляске на рубеже XIX в. / Военная литература. URL: // http://militera.lib.ru/explo/ira/2_01.html (дата обращения: 10.09.2021).

16. Первопроходчество. Глава 2. Битвы за Ситху и падение Якутата / Военная литература. URL: http://militera. lib.ru/explo/ira/2_02.html (дата обращения: 10.09.2021).

17. Подробная карта Калифорнии - Планетолог.ру / douala.ru. URL: https://yandex.ru/images/search?pos=6\&img url=https\%3A\%2F\%2Fsprtqa.b-cdn.net\%2Fdownload\%2F2ff4c4191252639a90aaec5da85c1c50_i-3122.jpg\&text= \%D0\%B2\%D0\%B5\%D1\%80\%D1\%85\%D0\%BD\%D1\%8F\%D1\%8F\%20\%D0\%BA\%D0\%B0\%D0\%BB\%D0\%B8\%D1\%84 \%D0\%BE\%D1\%80\%D0\%BD\%D0\%B8\%D0\%BA\%D0\%B0\%20\%D0\%BD\%D0\%B0\%20\%D0\%BA\%D0\%B0\%D1\%80\%D 1\%82\%D0\%B5\&lr=213\&rpt=simage \&source=wiz (дата обращения: 29.08.2021).

18. Подробная карта рельефа Вашингтона - Planetolog.ru / douala.ru. URL: https://yandex.ru/images/search?fr om=tabbar \&text=\%D1\%88\%D1\%82\%D0\%B0\%D1\%82\%20\%D0\%B2\%D0\%B0\%D1\%88\%D0\%B8\%D0\%BD\%D0\%B3 \%D1\%82\%D0\%BE\%D0\%BD\%20\%D0\%BD\%D0\%B0\%20\%D0\%B3\%D0\%B5\%D0\%BE\%D0\%B3\%D1\%80\%D0\%B0\%D 1\%84\%D0\%B8\%D1\%87\%D0\%B5\%D1\%81\%D0\%BA\%D0\%BE\%D0\%B9\%20\%D0\%BA\%D0\%B0\%D1\%80\%D1\%82\%D 0\%B5\&pos=13\&img_url=http\%3A\%2F\%2Fplanetolog.ru\%2Fmaps\%2Fusa-state\%2Fbig\%2Fsat\%2Fwashington2. jpg\&rpt=simage (дата обращения: 14.08.2021).

19. Пушная торговля на Тихоокеанском севере и отношения с «бостонцами» / Livejournal. 27.10.2014. URL: https://odynokiy.livejournal.com/798754.html (дата обращения: 30.06.2021).

20. Пушная торговля на Тихоокеанском севере и отношения с «бостонцами»...(2) / Livejournal. 28.10.2014. URL: https://odynokiy.livejournal.com/801591.html (дата обращения: 30.06.2021).

21. Территориальная эволюция США / Википедия. URL: https://ru.abcdef.wiki/wiki/Territorial_evolution_of_the_ United_States\#1819\%E2\%80\%931845_(Northwest_expansion) (дата обращения: 09.08.2021).

22. Форт Астория - Fort Astoria / Википедия. URL: https://ru.abcdef.wiki/wiki/Fort_Astoria (дата обращения: 09.08.2021).

23. Ханнан Д. Что было бы, если бы Америку колонизировали русские / in.иносми.ру. 02.09.2013. URL: https:/ inosmi.ru/world/20130902/212420220.html (дата обращения: 26.06.2021). 